\begin{tabular}{c} 
Volume and Issues Obtainable at Center for Sustainability Research and Consultancy \\
Journal of Business and Social Review in Emerging Economies \\
ISSN: 2519-089X (E): 2519-0326 \\
Volume 3: Issue 2December 2017 \\
CSRᄃ \\
Journal homepage: $\underline{\text { www.publishing.globalcsrc.org/jbsee }}$ \\
\hline
\end{tabular}

\title{
Do CPEC Power Plants Impact Pakistan'sEnvironmental Condition: Evidence from Literature
}

\author{
${ }^{1}$ Muhammad Ali Abuzar, ${ }^{2}$ Masood-Ul-Hassan \\ ${ }^{1}$ Research Scholar, Department of Commerce Bahauddin Zakariya University, Multan, Pakistan, \\ naqvi.abuzar08@gmail.com \\ ${ }^{2}$ Department of Commerce Bahauddin Zakariya University, Multan, Pakistan, masood@ bzu.edu.pk \\ ARTICLEDETAILS \\ History \\ Revised format: Nov 2017 \\ AvailableOnline: Dec 2017

\section{Keywords \\ CPEC, \\ Obor, \\ Energy crisis, \\ Coal, \\ Pakistan} \begin{abstract}
Purpose:With the increase in the population of the world and with the increase in the civilizations the need of humanity is increasing day by day. Now people need electricity for the meeting of their needs. From the period of 2000s Pakistan is suffering from the problem of load shedding. Load shading results in the poverty, hunger and unemployment. Government of Pakistan is keen to solve the power shortages problem and for this in 2013, CPEC idea was emerged, China government aims to invest in Pakistan and they have will to solve this problem. However environmental experts have shown their concerns regarding the use of coal in electricity production. With the help of literature available this point established that there are environmental hazards that will surely harm the environment.
\end{abstract}

JEL Classification:

O11, O12, N85

(C) 2017 The authors, under a Creative Commons Attribution-

NonCommercial 4.0

Corresponding author's email address: masood@bzu.edu.pk

Recommended citation:Ali, M.A. \&Hassan, M., (2017). Do CPEC Power Plants Impact Pakistan'sEnvironmental Condition: Evidence from literature.Journal of Business and Social Review in Emerging Economies, 3(2) 227234.DOI:https://doi.org/10.26710/jbsee.v3i2.187

\section{Introduction}

\subsection{Back Ground}

It is without hyperbole and ahead of the doubt that energy has become one of the most major needs of the human being. The utility of energy has greatly evolved over the last century. The whole range of human activities including private residence, trade and commerce, industry, haulage and agriculture has mostly become depended on energy. Worldwide, energy prosperity has become very crucial to overcome basic social problems such as poverty, hunger, disease and illiteracy. Word's total population over all is 7.5B and words population growth rate is $4.1 \%$ (wordometer,17). Pakistan is the sixth most populated country in the world with the estimated population of $21 \mathrm{M}$. Population growth and fertility rate is 1.86 and 2.6.0\% respectively (Economic survey of Pakistan, 2016-17). Government of Pakistan is very serious about the rapid increase in the population and he is taking serious steps regarding this. Pakistan population is $2.56 \%$ of total words population which obviously meant that among every 39 souls, one soul is of Pakistani. 


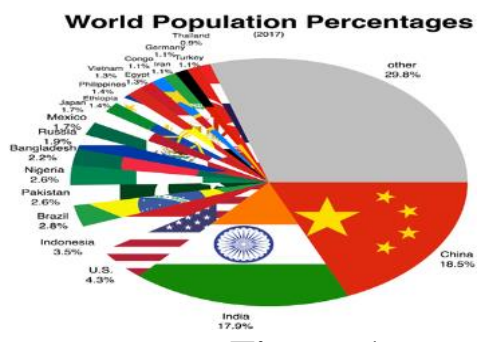

Figure:1

Table 1. Source: Pharma Asia,2017

\begin{tabular}{|l|l|l|l|l|l|l|}
\hline Actual & Previous & Highest & Lowest & Dates & Unit & Frequency \\
\hline 193.56 & 189.87 & 193.56 & 45.85 & $1960-2016$ & Million & Annually \\
\hline
\end{tabular}

As the above figures are showing that Pakistan population is increasing very fast, in the same way energy consumption is also increasing. Due to poor planning of Pakistan rulers we are now facing the problem of load shading. According to private infrastructure board government of Pakistan, the demand and supply of electricity during the period 2011-2017 is as follows.

\begin{tabular}{|l|l|l|l|l|l|l|l|}
\hline & $2 \mathrm{k} 11$ & $2 \mathrm{k} 12$ & $2 \mathrm{k} 13$ & $2 \mathrm{k} 14$ & $2 \mathrm{k} 15$ & $2 \mathrm{k} 16$ & $2 \mathrm{k} 17$ \\
\hline $\begin{array}{l}\text { Expected } \\
\text { availabe } \\
\text { generation }\end{array}$ & $18503 \mathrm{MW}$ & $20814 \mathrm{MW}$ & $21167 \mathrm{MW}$ & $23368 \mathrm{MW}$ & $23538 \mathrm{MW}$ & $24408 \mathrm{MW}$ & $25630 \mathrm{MW}$ \\
\hline $\begin{array}{l}\text { Demand } \\
\text { summer } \\
\text { peak }\end{array}$ & $19352 \mathrm{MW}$ & $20874 \mathrm{MW}$ & $22460 \mathrm{MW}$ & $24126 \mathrm{MW}$ & $25919 \mathrm{MW}$ & $28029 \mathrm{MW}$ & $30023 \mathrm{MW}$ \\
\hline $\begin{array}{l}\text { Deficit } \\
\text { Generation }\end{array}$ & $-849 \mathrm{MW}$ & $-60 \mathrm{MW}$ & $-1293 \mathrm{MW}$ & $-758 \mathrm{MW}$ & $-2381 \mathrm{MW}$ & $-3621 \mathrm{MW}$ & $-4593 \mathrm{MW}$ \\
\hline
\end{tabular}

Table 2. Source: Private Power and Infrastructure Board- Government Of Pakistan

According to the WAPDA vision 2025, the Water and Power development authority aims to complete the following projects by the end of 2025.(a) Completion of Indus Basin Replacement Projects, which includes the construction of 5 Barrages, 8 inter-river link canals, Mangla and Terbala Dams. (b) Ghazi Brotha Hydro power project. (c) Khan Khower Hydro Water Project. (d) Development of 5 dams, 3 Mega Canals, 5 Hydro Power projects, 2-drainage projects-RBOD-I and RBOD-III(under implementation), 25000MW Electricity. In view of the vision 2025, and with the aim to fulfill the vision Government of Pakistan after council of common interest meeting, Pakistan gave the national power policy in 2017. According to this policy to overcome the energy demands, government of Pakistan will invite the different investors for different power and water projects (National Power Policy, 2017). GOP, in view of this all scenario has formulated certain objectives regarding the investors, these objectives include: (a) to provide the energy facilities at least cost, (b) to ensure the efficient use of natural resources, (c) to plant only those projects that are environment friendly (National Power Policy,2017). To accomplish all these projects there was a need of true and sincere friend who could help the Pakistan, obviously other than China no one is there whose friendship is sweeter than honey and deep than ocean. Using the concept of ancient Silk road, Pakistan find it as God gift and proposed the idea of CPEC. At beginning there were only China and Pakistan but now more than 15 countries are interested in it (Quora,16). To build trade route between the China and the countries of central Asia, Europe and the countries that are situated on the Pacific Ocean. This road is the network of gas pipelines, petroleum pipe lines, railways, ports and grid station (Quora, 17). "One Belt Initiative" is progressing by leaps and bounds under the supervision of visionary Chinese leader "Xi. Jinping" in light of his ambitious planning's, with dawn of 2013 GOP inaugurated CPEC, with worthy investment of $\$ 55 \mathrm{~B}$ which is now raised to $\$ 62 \mathrm{~B}$ (Express Tribune,2017). However, keeping in view the serious problem of energy in Pakistan, the China will invest $\$ 35 \mathrm{~B}$ just in the energy projects which are total 19 in overall Pakistan (Dawn, 2017).

\subsection{Research Objective}

There are three research objectives. The first one is to know the actual causes of energy crisis. Second one is to know about the fact that whether this energy crisis is due to governance failure? Third one is to know 
that whether these said energy projects under CPEC are environment friendly.

\subsection{Research Methodology and Questions}

Following questions with the help of previous articles and newspaper will explore the research agenda.

- When was the idea of CPEC came?

- What do you think about CPEC investments?

- What do you know about CPEC energy projects?

- Do you think that energy problem is due to governance failure?

- What is your view point regarding environmental hazards of Pakistan?

- Do you think that these CPEC energy projects are environment friendly?

\section{Literature Review}

To support the topic this section will include several literature of books, research articles and other material.

\subsection{One Belt One Road:}

One belt one road (OBOR) which is also known as "silk route". The reason to call, this route as "silk route" is that at that time silk was derived from these countries who were specialized in the silk production and also in the horse trading. Silk industry was begun around 5000 and $3000 \mathrm{BC}$ in China. It reached India around 140 AD. Silk route was also used to export the worm eggs into the Mediterranean and from there into rest of Europe (World atlas,17) Central Eurasia was famous for its horse riding communities and horse breeding also. However, due to poor infrastructure Chinese were having trouble in transportation of their goods in the safe way. For this purpose China extended "wall of China" for the safety assurance of their trade (Quora,16). Trade on this silk route resulted in the development of Chinese civilization. With the passage of time, China realize the importance of trade zones as it was the necessity of time. Keeping in view the geographical boundaries, and looking at the importance of Gawadar Port, Xi Jinping presented the idea of silk route in the advance form that is "OBOR" in 2013. According to China's greater neighborhood policy (CGNP), Xi Jinping has ambitious vision of connecting China to central Asia and Europe (Fallon, 16). Specially one trustworthy Chinese official statement that was issued by "Ministry of foreign affairs and ministry of commerce in 2015 was: "The Belt and Road run through the continents of Asia, Europe, and Africa, connecting the vibrant East Asia economic circle at one end and developed European economic circle at the other, and encompassingcountries with huge potential for economic development. The Silk Road Economic Belt focuses on bringing together China, Central Asia, Russia and Europe (the Baltic); linking China with the Persian Gulf and the Mediterranean Sea through Central Asia and West Asia; and connecting

China with Southeast Asia, South Asia and the Indian Ocean. The 21st- Century Maritime Silk Road is designed to go from China's coast to Europe through the South China Sea and the Indian Ocean in one route, and from China's coast through the South China Sea to the South Pacific in the other".

\subsection{China-Pak Economic Corridor}

China - Pakistan economic corridor (CPEC) is well known project around the world. In 2013 China's President, Xi Jinping, proposed the idea of establishing economic corridors, linking China with Centre Asia, West Asia and some regions of South Asia called the "One Belt One Road (OBOR)" initiative ( Global infrastructure initiative,16). CPEC is the part of OBOR, that is initiated by the investment of \$51B (Dawn,16). Apart from the political gains, CPEC strategies will help the China to find new markets and opportunities across the world (Economist, 17). Pakistan is the victim of energy crisis, due to these crisis power experts report "according to safe estimate there is the loss of \$100B to Pakistan economy (Dawn, 17). Pakistan on average facing the GDP loss of 2 to $2.5 \%$. It is estimated that CPEC projects will help the Pakistan economy to boost and to fight against this GDP loss (Economist, 17). The main hurdles that 
Pakistan economy is facing, includes continuous industrial loss due to poor foreign direct investment(FDI), poor infrastructure, energy crisis and war on terror( Dawn,16). According to vision 2025, Pakistan aims to produce the $42000 \mathrm{MW}$ and to provide uninterrupted and affordable energy (Vision, 2025). One of the key objectives of CPEC is to provide the best infrastructure as well as to take Pakistan out of this monster of energy crisis.

\subsection{Power Crisis in Pakistan}

Around, $140 \mathrm{M}$ people in Pakistan do not have energy access and they suffer from 12 hours of load shading (Dawn, 16). Poor governance, opposition to different electric projects and water reserves lead to the huge gap in the demand and supply of energy in Pakistan (Nation, 16). If we want to check the prosperity of any country then "Human Development Index" (HDI) is very important in the same as "Gross National Investment"(GNI) is an integral variable in calculation of HDI(United Nations Development Program,17). As we all know that per capita consumption of energy is an important as it is a measure of socioeconomic progress of country (International Energy Agency IEA, 16). A rough data shows that there are 12000 villages in Pakistan, among them 95000 villages are electrified and some 30000 villages are to be electrified (Nation, 2016). By reading this, question come in my mind that on average 14 crore people in Pakistan does not have the facility of fan, bulb and proper water. Remember, this all happening in $21^{\text {st }}$ century. This is the reason, in vision 2025 Pakistan aims to give access of electricity to $65 \%-90 \%$ (Vision, 2025). This dream looks like fantasy but could be fulfilled by the CPEC projects that will accomplish in 2030.

\subsection{Sources Of Energy In Pakistan}

Before describing and telling details about the sources of energy in Pakistan, it is needed that world energy should be describe. According to physics, energy is defined as: energy, in physics, the capacity for doing work. It may exist in potential, kinetic, thermal, electrical, chemical, nuclear, or one body to another (Editors of Encyclopedia of Britain, 2017). After describing the energy definition now there is the list of energy sources in Pakistan.

\section{Figure 2.}

\section{Sources of Energy in Pakistan}

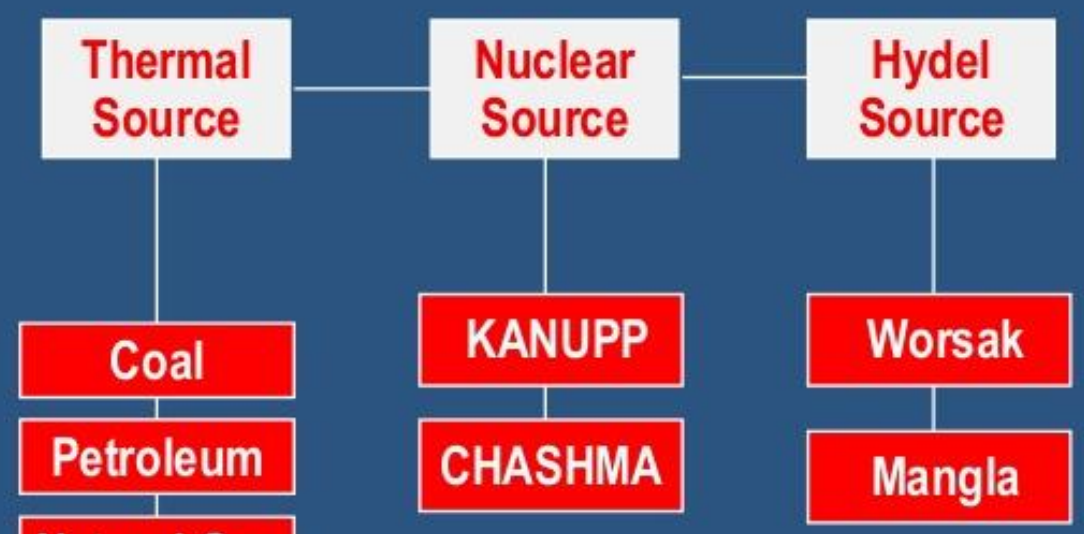

\section{Natural Gas}

Oil 


\subsection{Thermal Sources of Energy}

\subsubsection{Coal}

Coal contributes $0.2 \%$ in meeting the energy resources of Pakistan. Some of it is used in just as the heat process while other are used as the domestic purposes however this is not environment friendly. Pakistan with the help of China under the project of CPEC is keen to solve the problem by the help of coal however the environmental experts had shown their serious concerns by using the coal in Sahiwal power plant (Dawn, 17).

\section{Coal converted into electricity}

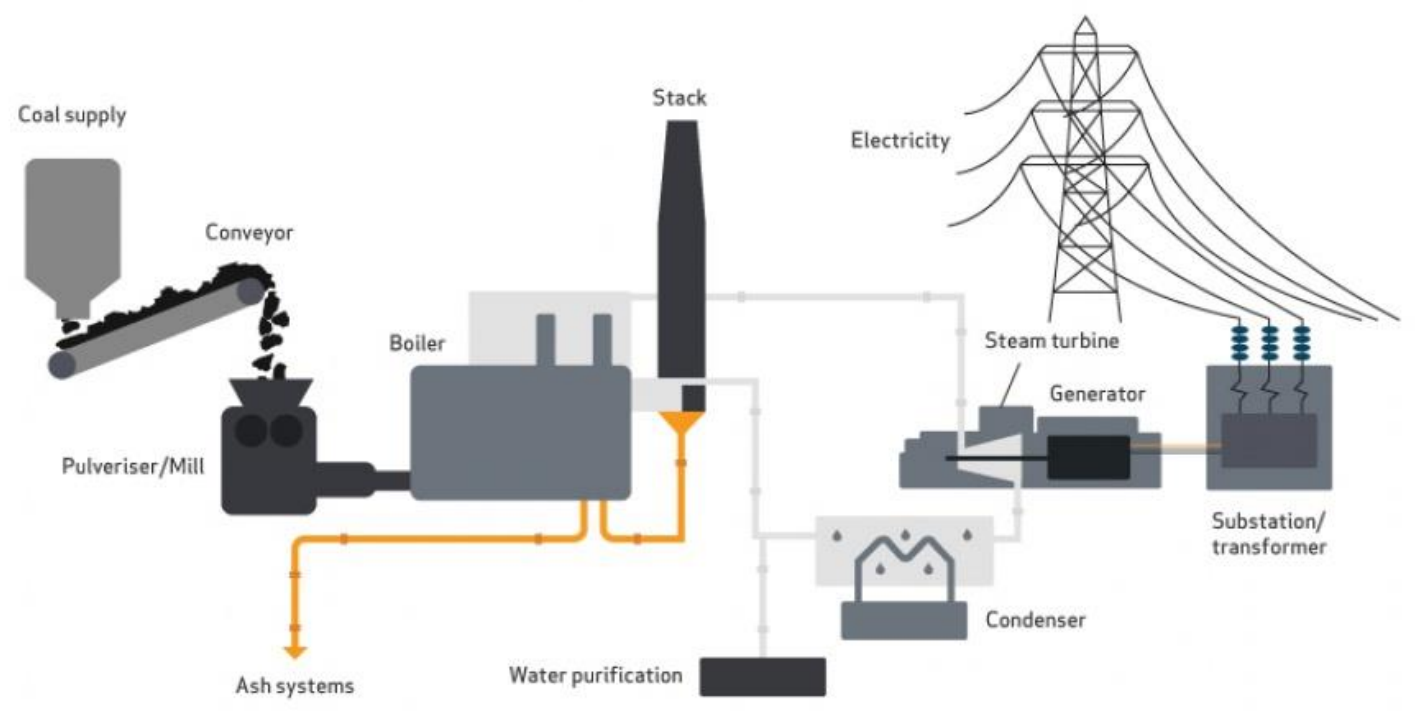

\subsubsection{Petroleum, Natural Gas and Oil}

After looking the immense business opportunities in the petroleum sector in Pakistan, foreigners are looking towards this sector and there is the investment of $\$ 10 \mathrm{~B}$ in this sector (Dawn, 17). Natural gas also plays its role in the power generation of any country, although we are enrich with the natural gas resources in Baluchistan, but due to ill planning and poor administration we are ruining this volume of gas is sufficiently to run 2.4 MW of power (Dawn, 17). Oil plays its role in the power generation of any country although it's an expensive source of generation yet due to poor condition of power in Pakistan we are using oil as source of power generation. Keeping in view all this government of Pakistan in collaboration with Parco will generate 6,600MW in Gadani, Baluchistan (Dawn, 16).

Figure 3.

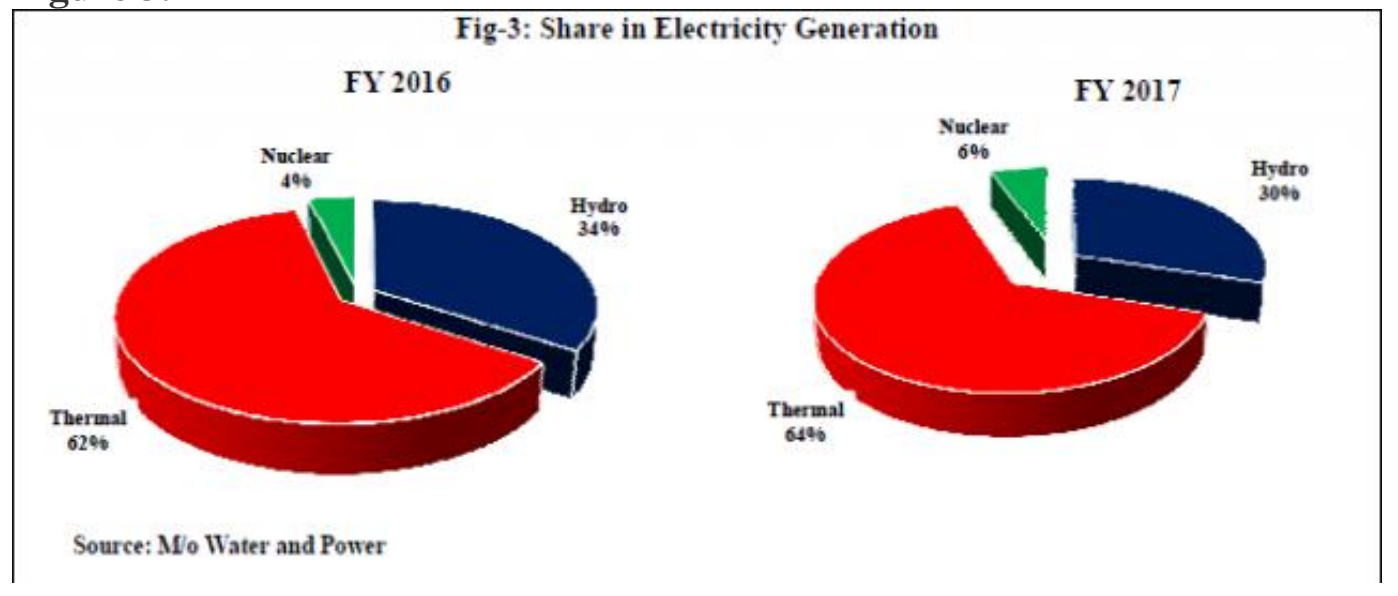




\subsubsection{Nuclear Sources}

It is without hyperbole and a head of doubt that Pakistan has more safe nuclear resources and they are safer than any country has. October 1998, was the time when team under the supervision of Dr. Abdul Qadeer, done experiments of atomic blast and Pakistan emerged as $7^{\text {th }}$ nuclear power of the world and first nuclear Islamic world. Pakistan's nuclear resources are not for creating imbalances in the region but they are for our own safety. Due to poor energy conditions now its time to utilize the nuclear resources. In this regard China is helping Pakistan to use their nuclear resources in this regard K-2 and K-3 are being built by China Nuclear Corporation $(\mathrm{CNC})$ it will be build on the design of China, nuclear power plant. Its early cost was nearly $\$ 10 \mathrm{~B}$ and we will be able to generate $1100 \mathrm{MW}$ of electricity (Dawn, 17). According to Ministry of foreign affairs, Pakistan the international atomic agency Pakistan took the responsibility to safe guard the nuclear plants, K-2 and K-3(Dawn, 17).

\section{Figure 4.}

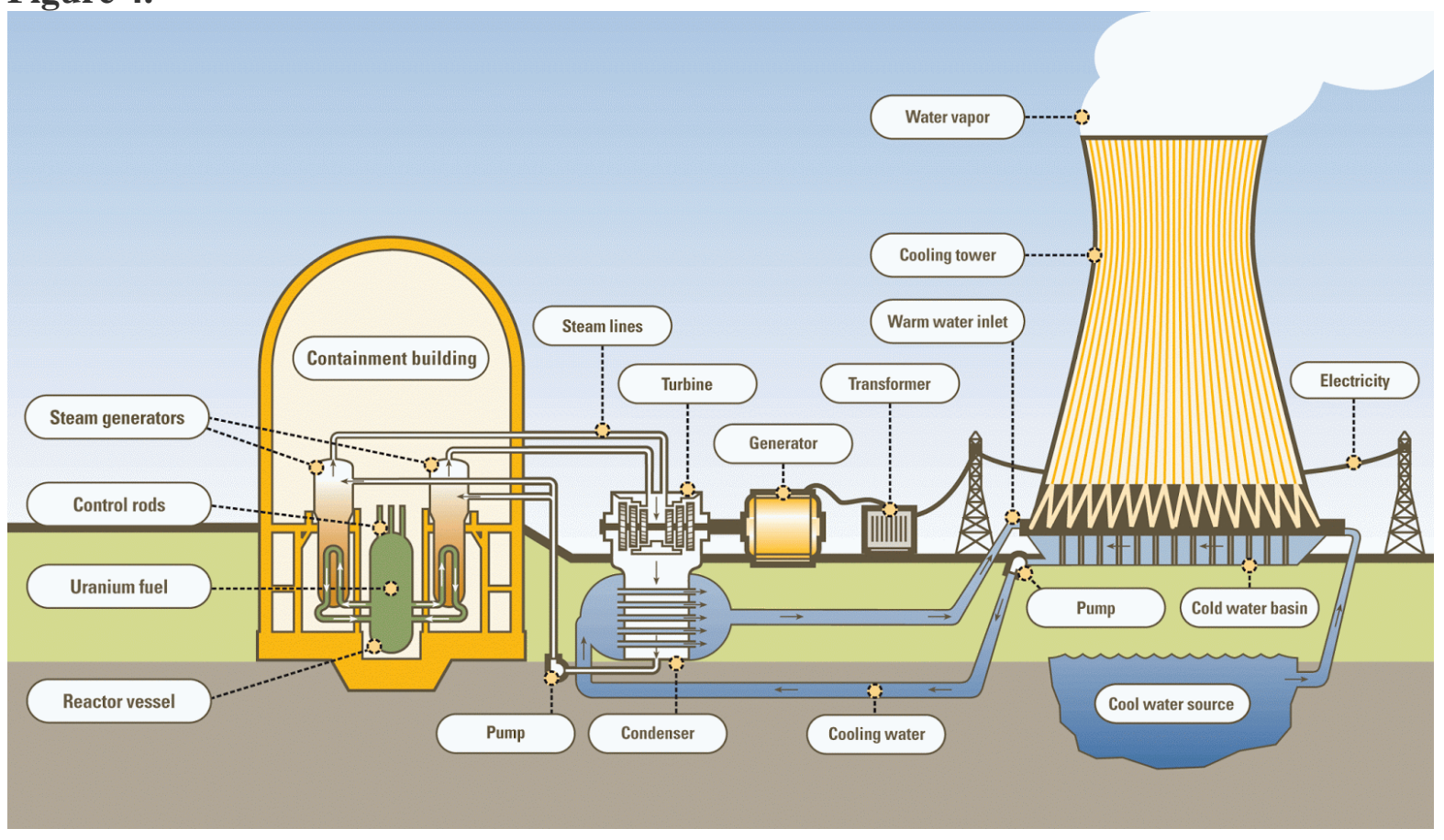

\subsubsection{Hydal Sources Of Energy}

This source of energy generation is the cheapest source of energy in Pakistan. Pakistan went through the contract of Sindh Taas agreement. Pakistan is now looking for the hydel projects and they are very keen to solve the energy problems. Land of Khyber PakhtunKhaw is enriching with little dams however due to lack of funding these dams are not completed and Pakistan is not able to fulfill their needs of energy through hydel (Dawn, 16).

\subsubsection{Coal and its affect On Environment}

According to the environmental experts coal is very damaging to the health and also to the environment. As we all know that coal fired power plants includes sulfur dioxide, nitric acid that leads to smog, acid rain and other toxic products (Environment aspects of coal).

\subsubsection{Coal Reserves in Pakistan}

Federal Ministry of Planning and Development says that the coal which has found in the "Thar" will last for the 400years for Pakistan. For this purpose two transmission lines are to be placed there out of these two one will be till Lahore and other till Faisalabad which both these lines will connect to National Grid(Dawn,17). 


\subsubsection{Coal Power Plants affect on Pakistan}

During the answer session in the senate committee on "environmental issues" minister for Climate change said that these power plants will increase greenhouse gases, and will lead to the other environmental issues. Moreover, he also provide the details of the under construction coal power plants.

- $40 \mathrm{MW}$ Maple leave in Mianwali.

- 330MW Tharparker.

- 350 MW Siddique sons Karachi.

- 720 MW K-Electric Coal power plants.

- $\quad 120 \mathrm{MW}$ sugar cane Muzaffargarh power plant

These all were reported by Dawn in 2016.

\section{Conclusion}

As the people of south Punjab are not well informed about different aspects of policies and we also know that the information about CPEC is in different pockets. What I was able to gain the knowledge was through the previous research articles and through the leading newspapers. I was able to get the knowledge about CPEC projects on environment. Media reports and official personal data showed that there is the environment aspects however there is further need of improvement and future researchers are encouraged to test this with the help of empirical investigation.

\section{Reference}

Hunt LC, Judge G, Ninomiya Y. Modelling underlying energy demand trends chapter 9. In: Hunt LC, editor. Energy in competitive market: essays in honour of Colin Robinson. UK: Edward Elgar; 2003. p. $140 \mathrm{e} 74$.

Hunt LC, Judge G, Ninomiya Y. Modelling underlying energy demand trends chapter 9. In: Hunt LC, editor. Energy in competitive market: essays in honour of Colin Robinson. UK: Edward Elgar; 2003. p. $140 \mathrm{e} 74$.

Hunt LC, Ninomiya Y. Unravelling trends and seasonality: a structural time series analysis of transport oil demand in the UK andJapan. Energy J 2003;24:

63e9.Institute of strategic stiudies Pakistan.

Asif Muhammad,(2011), Energy crisis in Pakistan origins challenges and sustainable Solutions, Karachi: Oxford University Press.

Dincer, M.Rosen, Energy Environment and subtainable Development, Applied Energy)

UNDP, Human Development Report (2007-08), Poverty Energy and Society Energy forum, Rice University, the Baker institute ND.

M.Asif and T.Muneer, (2007) Energy supply its Demond and security issues for Developed and Emerging Economics, Renewable \& Sustainable Energy Reviews,(Vol 11),(issue 7) (Asif,2011).

WAPDA, (December 11,2009), WWW.Wapda.gov.pak.

Pakistan Atomic Energy Commission, website, Islamabad. 
